\title{
Variation in Microbial Community Composition and Culturability in the Rhizosphere of Leucanthemopsis alpina (L.) Heywood and Adjacent Bare Soil Along an Alpine Chronosequence
}

\author{
I.P. Edwards, H. Bürgmann, C. Miniaci and J. Zeyer \\ Institute of Terrestrial Ecology, Federal Institute of Technology (ETH), ETH Zentrum CHN G47 Universitätstrasse 16, CH-8092 Zurich, Switzerland
}

Received: 6 January 2006 / Accepted: 30 January 2006 / Online publication: 15 August 2006

\begin{abstract}
We compared the size, culturability, diversity, and dominant species similarity of the bacterial communities of Leucanthemopsis alpina (L.) Heywood rhizosphere and adjacent bare soil (interspace) along a chronosequence of soil development time (5, 50, and 70 years) in the forefield of the Dammaglacier (Switzerland). We found no evidence that the size of the bacterial community was significantly affected by either soil age or the presence of $L$. alpina. In contrast, the proportion of the bacterial community that could be cultured on nonselective agars, and which was taken as an indication of the proportion of $r$-selected populations, was significantly higher in the 50- and 70-year-old soils than in the 5-year-old soil, and was also significantly higher in the rhizosphere of $L$. alpina at all time points. RDA indicated significant correlations between the increased culturability of the bacterial community over time and increasing concentrations of labile $\mathrm{N}$, and between the increased culturability in the rhizosphere and increased concentrations of labile C and N. HaeIII-amplified ribosomal DNA (rDNA) restriction analysis of a library of 120 clones of $16 \mathrm{~S}$ rDNA revealed 85 distinct phylotypes. Hurlbert's probability of interspecific encounter (PIE) values derived from this library ranged from 0.95 to 1.0 , indicating a very high genetic diversity. There was no significant difference in the PIE values of rhizosphere and interspace communities. Detrended correspondence analysis (DCA) of $16 \mathrm{~S}$ ribosomal RNA (rRNA) denaturing gradient gel electrophoresis (DGGE) community profiles clearly distinguished the rhizosphere from the interspace community
\end{abstract}

Present address of I.P. Edwards: School of Natural Resources and Environment, University of Michigan, Dana Building, 440 Church Street, Ann Arbor, MI 48109-1041, USA

Present address of $\mathrm{H}$. Bürgmann: Department of Marine Sciences, University of Georgia, Athens, GA 30602-3626, USA

Correspondence to: J. Zeyer; E-mail: josef.zeyer@env.ethz.ch in the 5-year-old soils and also clearly distinguished between these communities and the rhizosphere and interspace communities of the 50- and 70-year-old soils. However, 16S rRNA DGGE revealed little difference between rhizosphere and interspace communities in the 50and 70-year-old soils. The relative similarity of the $16 \mathrm{~S}$ rRNA profiles strongly reflected labile carbon and nitrogen availability. Overall, our results suggest that improved $\mathrm{C}$ and $\mathrm{N}$ availability in the rhizosphere of $L$. alpina increases the size of $\mathrm{r}$-selected bacterial species populations, but that the influence of L. alpina depends on soil age, being maximal in the youngest soils and minimal in the oldest. The reduced influence of $L$. alpina in the older soils may reflect a feedback between improved nutrient availability and reduced rhizodeposition.

\section{Introduction}

Increasing global atmospheric temperatures over the last decades have resulted in the recession of alpine glaciers, exposing fresh glacial till to colonization by plants and microorganisms and creating ecosystems in which plant and microbial community development can be studied in the context of primary succession $[9,40-42]$. The colonization of recently deglaciated sediments by pioneering plants initiates a process of soil development, which, in turn, creates environmental conditions suitable for the establishment of a more diverse and productive plant community [9]. Key factors of this process appear to be the long-term accumulation of soil organic matter and associated changes in nutrient availability and soil $\mathrm{pH}[9$, 15]. These same factors are likely to influence the development of the soil microbial community, as microorganisms in soils are typically carbon and nutrient limited for growth [10, 16, 45]. Carbon and nitrogen limitations may be exacerbated in young alpine soils 
which typically have a high fraction of coarse-grained mineral skeleton and low total carbon and nitrogen contents $[15,22]$. Nitrogen limitation has been recorded in the microbial communities of both arctic [25] and alpine soils [28], and a positive relationship between microbial biomass and soil organic carbon content has been observed in the forefields of the Lyman Glacier (Washington, USA) [41], and the Rotmoosferner and Ödenwinkelkess glaciers (Austria) [49, 50]. Our previous work in the forefields of the Dammaglacier and Rotfirnglacier in the Swiss Alps also revealed considerable differences between the dominant bacterial populations along chronosequences of soil age [44], and similar differences have also been recorded in other alpine glacier forefields [49]. Such differences may be an example of long-term succession analogous to that seen in the plant community and may reflect gradients of substrate and nutrient availability $[26,44]$.

In addition to long-term changes, the exudation of photosynthetically fixed carbon in the rhizosphere of plants [36] creates local patches of enhanced nutrient availability in which microbial growth is stimulated [24]. Quantity and quality of rhizodeposits is often plant specific and may favor the development of characteristic rhizosphere microbial communities [19, 30, 34, 52]. For example, distinct bacterial communities have been observed in the rhizospheres of Bromus tectorum, Stipa hymenoides, and Hilaria jamesii growing together in the Colorado plateau [28], and between the bacterial communities of adjacent Nardo-Galion- and Lolio-Plantaginion-type grasslands in Ireland [5]. Alpine plant species exhibit adaptations to their environment, such as perennial growth, extensive fine root development, and increased root longevity [27], which may enhance the selective effect of rhizodeposition [21, 49]. The colonization of recently deglaciated soil by pioneer plants could therefore create nutrient enriched "hotspots" in which microbial growth and activity exceed that of unvegetated patches of similar age and characterized by distinct bacterial communities [42].

We hypothesized that in the forefields of receding alpine glaciers, the development of the microbial communities is therefore driven by exposure to two gradients of carbon and nitrogen availability. These two gradients are a long-term gradient resulting from soil development and a local gradient created by current plant growth and rhizodeposition. We predicted that (1) the long-term gradient would lead to qualitative and quantitative differences between the microbial communities of recently deglaciated and older soils, but also that (2) as a result of rhizodeposition, alpine plants would develop characteristic rhizosphere microbial communities independent of the age of the soil in which the plants were located. To test our hypotheses, we chose to target the bacterial communities developing in both the root zone of $L$. alpina and in adjacent patches of unvegetated soil along a chronosequence of soil age. L. alpina was chosen because in the forefield of the Dammaglacier, it colonizes both recently exposed glacial tills and older soils. We used a combination of traditional methods and culture-independent techniques to examine the relative size and compositional similarity of the bacterial communities, and ordination techniques to relate these observations to the $\mathrm{C}$ and $\mathrm{N}$ gradients.

\section{Methods}

Field Site and Collection of Samples. The forefield of the Dammaglacier $\left(8^{\circ} \mathrm{E} \quad 27^{\prime} 30^{\prime \prime} 46^{\circ} \mathrm{N} 38^{\prime} \quad 00^{\prime \prime}\right)$ in Göscheneralp, Canton Uri, Switzerland, is $\sim 2000 \mathrm{~m}$ above mean sea level at the glacier toe. The site includes over 150 ha and slopes downward (25\% slope) over 1500 $\mathrm{m}$ toward the northeast. The glacier has probably been receding since ca. 1850, and a net recession of $400 \mathrm{~m}$ has been recorded since 1922 [22], despite advancing between ca. 1972 and 1992 (Fig. 1). During the last decade, the glacier retreated with a mean rate of $11 \mathrm{~m}$ year ${ }^{-1}$. The site has a mean annual temperature of between 0 and $5^{\circ} \mathrm{C}$, and a mean precipitation of $2400 \mathrm{~mm}_{\text {year }}^{-1}$ [46].

Samples were collected shortly after snowmelt in May 2003 at three distances from the glacier toe representing different soil ages (Fig. 1). At each distance, three collections of L. alpina soil (rhizosphere, sample designation: $\mathrm{Rh}$ ) and three collections of nonvegetated soil (interspace, sample designation: In) were made. L. alpina plants $(2-5 \mathrm{~cm}$ diameter) were chosen such that an adjacent interspace patch was located within $15 \mathrm{~cm}$ of the plant. For interspace samples, a small soil core $\sim 2 \mathrm{~cm}$ in

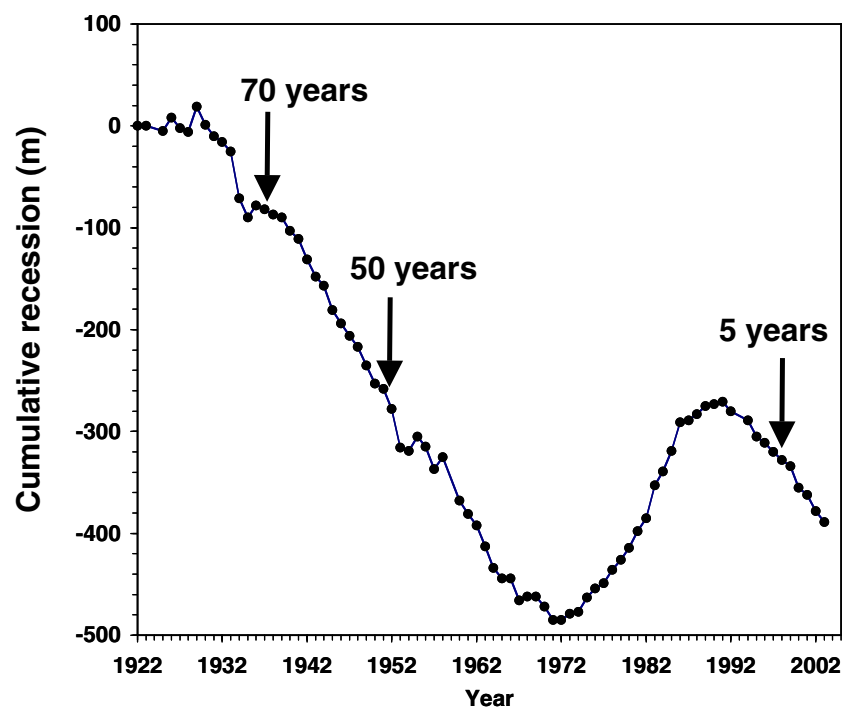

Figure 1. Cumulative recession of the Dammaglacier since 1922, indicating the three stages of soil age sampled in this study. 
diameter and 2-3 cm deep was taken, bagged, and transported on ice back to the laboratory. For L. alpina rhizosphere, the plant was excavated and the soil within the root zone was retained. The youngest soil was sampled 40-60 $\mathrm{m}$ from the current toe of the glacier and has been ice-free for approximately 5 years (samples Rh5, In5). Soils here have a coarse sandy-gravel texture, and plant community development is restricted to scattered pioneer plants. The second youngest soil was sampled at $80-100 \mathrm{~m}$ from the glacier terminus, corresponding to a soil age of 50 years (samples Rh50, In50). Here, plant community development is more advanced, although vegetation cover is still patchy. The oldest soil was sampled $320-350 \mathrm{~m}$ from the glacier terminus, corresponding to a soil age of 70 years (samples Rh70, In70). Vegetation cover here is essentially contiguous. Within the 5-year-old soil, where L. alpina was sparsely distributed, we were only able to locate and sample two plants; in total, 16 samples were taken. All soils were sieved to remove the $>4 \mathrm{~mm}$ coarse fraction and stored at $-20^{\circ} \mathrm{C}$ until analysis.

Chemical Properties of Rhizosphere and Interspace Soils. Field moist subsamples of each soil (1.0-2.0 g) were extracted with cold deionized water for $1 \mathrm{~h}$ (1:5 soil/ extractant ratio). Nitrate and the concentrations of lactic, acetic, butyric, propionic, malic, oxalic, and citric acids (in their anionic forms) were determined by ion chromatography with suppressed conductivity detection (Dionex ${ }^{\circledR}$ Corporation Document 031373). Soil pH was determined in the same solution [48]. Dissolved organic carbon (DOC) was determined by combustion of an aliquot of the cold-water extract (TOC-5000, Shimadzu Europa, Duesberg, Germany). Dissolved organic nitrogen (DON) was estimated as the increase in nitrate after oxidation of an aliquot of the cold-water extract with alkaline $\mathrm{K}_{2} \mathrm{~S}_{2} \mathrm{O}_{8}$ [54]. Total sugars in solution were determined as glucose equivalents after acid hydrolysis [8]. Potentially available ammonium was extracted in 2 $\mathrm{N} \mathrm{KCl} \mathrm{(1:5} \mathrm{soil/extractant)} \mathrm{for} 1 \mathrm{~h}$ at room temperature and determined colorimetrically [37]. Total organic carbon (TOC) was determined by combustion of ground air-dried soil samples (LECO 932 CHNS, Leco, Krefeld, Germany).

Total Cell Counts and Proportion of Culturable Bacteria. Field moist subsamples of each soil were treated with $4 \%$ paraformaldehyde in phosphate-buffered saline ( $\mathrm{pH} 7$ ) to fix bacterial cells, and the total number of bacteria in each sample was estimated by direct microscopic counting following $4^{\prime} 6$-diamidino-2phenylindole (DAPI) staining [53]. Both samples and slides were prepared in duplicate, and 10 fields per slide were counted.
Culturable bacteria were enumerated on tryptone soy agar (TSA), $\mathrm{R}_{2} \mathrm{~A}$, and cold soil extract agar (CSEA) media. TSA was prepared as per instructions of the manufacturer (Fluka Production, Buchs, Switzerland). $\mathrm{R}_{2} \mathrm{~A}$ medium was prepared from (per liter) $0.50 \mathrm{~g}$ yeast extract, $0.50 \mathrm{~g}$ proteose peptone, $0.50 \mathrm{~g}$ casein hydrolysate, $0.50 \mathrm{~g}$ glucose, $0.50 \mathrm{~g}$ soluble starch, $0.30 \mathrm{~g}$ sodium pyruvate, $0.30 \mathrm{~g}$ dipotassium hydrogen phosphate, $0.05 \mathrm{~g}$ magnesium sulfate, and $12.0 \mathrm{~g}$ agar. CSEA was prepared as described previously $[3,33]$. Briefly, $1 \mathrm{~kg}$ of a composite forefield soil (equal parts 5-, 50-, and 70-year-old bulk samples collected for a separate study) was extracted with shaking in $1 \mathrm{~L}$ of sterile deionized water overnight. After centrifugation (20 minutes, $4500 \mathrm{rpm}$ ), the supernatant was filtered $(0.2-\mu \mathrm{m}$ pore size). CSEA contained (per liter) $12.0 \mathrm{~g}$ agar, $400 \mathrm{~mL}$ cold soil extract, and 1.0 $\mathrm{mL}$ of a nutrient stock solution $\left(10.0 \mathrm{~g} \mathrm{~L}^{-1}\right.$ each of sodium citrate, sodium succinate, glucose, fructose, xylose, peptone, and yeast extract). Cycloheximide was added to all media at $50 \mu \mathrm{g} \mathrm{mL}^{-1}$ to inhibit fungal growth. Bacterial inoculum was obtained by serial dilution of a 1.0 -g field moist soil in $10-\mathrm{mL}$ sterile water suspension. Plates were incubated in the dark at $20^{\circ} \mathrm{C}$ for 3 days.

Extraction of DNA. Total DNA was extracted from $1.0-\mathrm{g}$ aliquots of field moist soil using a bead-beater technique as previously described [44], except that the final precipitation was performed with a $20 \%$ polyethylene glycol 6000 in $2.5 \mathrm{M} \mathrm{NaCl}$ solution at $37^{\circ} \mathrm{C}$ to remove traces of organic material [7]. The concentration of DNA was determined by UV absorbance at $260 \mathrm{~nm}$ [43]. Triplicate DNA extracts from each sampling point were subsequently pooled to facilitate PCR amplification from these low DNA soils $\left(<1-25 \mu \mathrm{g} \mathrm{g}^{-1} \mathrm{DNA}\right)$.

Denaturing Gradient Gel Electrophoresis. The similarity of bacterial communities was investigated after amplification of partial bacterial $16 \mathrm{~S}$ rRNA gene fragments with the universal bacterial primers U968f (5'GC clamp-AAC GCG AAG AAC CTT AC- $3^{\prime}$ ) and L1401r (5'-CGG TGT GTA CAA GAC CC-3') [13, 14, 17, 39, $52]$. Reactions were performed in a $50-\mu \mathrm{L}$ solution containing $1 \times$ PCR buffer, $2.0 \mathrm{mM} \mathrm{MgCl}_{2}, 0.2 \mathrm{mg} \mathrm{mL}^{-1}$ bovine serum albumin (BSA), $200 \mathrm{nmol}$ of each dNTP, $0.5 \mu \mathrm{mol}$ of each primer, approximately $50 \mathrm{ng}$ soil extract DNA, and 1 U Taq DNA polymerase Invitrogen, Carlsbad, CA 92008, USA. PCR amplicons were subsequently extracted once with an equal measure of chloroform, concentration was estimated by comparison with a mass standard after agarose gel electrophoresis, and approximately $500 \mathrm{ng}$ was loaded in each lane of a 35-60\% denaturing gradient $8 \%$ polyacrylamide gel. Electrophoresis was performed at $200 \mathrm{~V}$ and $60^{\circ} \mathrm{C}$ for $5 \mathrm{~h}$ and 
gels were stained with GelStar (Cambrex Bioscience, Baltimore, MA) before image capture. Quantity One software (Bio-Rad Laboratories, Hercules, CA) was used to determine the intensity and relative position of each band after applying a rolling disk background subtraction algorithm. These data were then used to construct a phylotype relative abundance matrix. We assumed that each distinct denaturing gradient gel electrophoresis (DGGE) band represented a distinct phylotype and that relative intensity is a reasonable measure of phylotype relative abundance $[13,14,17,35,44]$.

165 Random Clone Libraries. Nearly full-length bacterial 16S ribosomal DNA (rDNA) genes were selectively PCR amplified with the primer set 8-27F (5'-AGA GTT TGA TCC TGG CTC AG-3') [2] and L1401r. Amplification was performed in $50-\mu \mathrm{L}$ reactions containing $1 \times$ PCR buffer, $2.0 \mathrm{mM} \mathrm{MgCl}_{2}, 0.2 \mathrm{mg} \mathrm{mL}^{-1}$ BSA, 200 nmol of each dNTP, $0.5 \mu \mathrm{mol}$ of each primer, approximately 50 ng soil extract DNA, and 1 U Taq DNA poly- merase. Purified PCR products were cloned into vector pGEM $^{\circledR}$-T using a 3:1 insertion/vector ratio according to instructions of the manufacturer (Promega, Madison, WI). Ligations were transformed into competent Escherichia coli DH5a (Invitrogen, Karlsruhe, Germany) and 30 white colonies per microhabitat were picked and grown overnight in Luria broth. Plasmids were recovered with Wizard ${ }^{\circledR}$ SV R Plus minipreps (Promega), and the insert was reamplified with 8 -27F-L1401r as described above except that BSA was omitted from the reaction mixture. To select the dominant bacterial species for sequencing, amplified rDNA restriction analysis (ARDRA) was performed. Plasmid PCR products were digested overnight in appropriate buffer with $1 \mathrm{U}$ of HaeIII (Invitrogen). Restriction fragments were separated by electrophoresis on $2 \%$ Agarose-1000 (Invitrogen) gels at $80 \mathrm{~V}$ for $90 \mathrm{~min}$ utes in $1 \times$ TAE buffer, stained with ethidium bromide, and photographed under UV light. The U968f-L1401r partial $16 \mathrm{~S}$ rDNA gene fragment of plasmids with a common HaeIII ARDRA profile were subsequently screened

Table 1. Soil chemical and microbiological data for L. alpina rhizosphere and interspace soils at three time points along a chronosequence of ice-free soil development time as determined in May 2003

\begin{tabular}{|c|c|c|c|c|c|c|c|c|}
\hline & \multirow{2}{*}{\multicolumn{3}{|c|}{ Interspace }} & \multirow{2}{*}{\multicolumn{3}{|c|}{ Rhizosphere }} & \multicolumn{2}{|r|}{$p$} \\
\hline & & & & & & & Soil age ${ }^{a}$ & Rhizosphere $^{b}$ \\
\hline Age (years) & 5 & 50 & 70 & 5 & 50 & 70 & & \\
\hline $\mathrm{pH}$ & $6.54 \pm 0.06 \mathrm{a}$ & $6.24 \pm 0.06 b$ & $6.09 \pm 0.10 b$ & $5.37 \pm 0.15$ & $5.67 \pm 0.06$ & $5.78 \pm 0.08$ & 0.004 & 0.03 \\
\hline $\mathrm{TOC}^{c}$ & $0.08 \pm 0.04$ & $0.29 \pm 0.17$ & $0.25 \pm 0.09$ & $0.60 \pm 0.12$ & $1.07 \pm 1.32$ & $0.53 \pm 0.42$ & 0.23 & 0.013 \\
\hline $\mathrm{TDOC}^{d}$ & $79.2 \pm 20.9$ & $158 \pm 118$ & $172 \pm 49.0$ & $1688 \pm 962$ & $321 \pm 180$ & $241 \pm 117$ & 0.48 & 0.10 \\
\hline Sugars $^{d}$ & $137 \pm 49.3$ & $71 \pm 35.8$ & $209 \pm 16.4$ & $1175 \pm 460$ & $703 \pm 358$ & $612 \pm 417$ & 0.15 & 0.011 \\
\hline $\mathrm{TDOA}^{d}$ & $22.8 \pm 2.90$ & $16.1 \pm 1.78$ & $18.2 \pm 6.05$ & $427 \pm 115$ & $75.4 \pm 64.6$ & $20.6 \pm 7.78$ & 0.30 & 0.11 \\
\hline Oxalate ${ }^{d}$ & $0.87 \pm 0.65$ & $0.20 \pm 0.09$ & $1.15 \pm 1.01$ & $182 \pm 93.6$ & $20.6 \pm 26.9$ & $1.16 \pm 0.70$ & 0.08 & 0.004 \\
\hline Citrate $^{d}$ & $12.6 \pm 3.85$ & $8.60 \pm 0.77$ & $8.76 \pm 2.95$ & $215 \pm 25.5$ & $41.0 \pm 33.1$ & $8.56 \pm 2.78$ & 0.27 & 0.24 \\
\hline Malate $^{d}$ & $0.34 \pm 0.31$ & $0.51 \pm 0.04$ & $1.19 \pm 0.61$ & $12.2 \pm 3.06$ & $2.58 \pm 1.99$ & $1.07 \pm 0.82$ & 0.13 & 0.17 \\
\hline Acetate $^{d}$ & $4.02 \pm 0.28$ & $3.85 \pm 0.52$ & $3.83 \pm 0.82$ & $11.5 \pm 4.49$ & $6.52 \pm 2.32$ & $4.61 \pm 2.72$ & 0.94 & 0.21 \\
\hline Formate $^{d}$ & $2.64 \pm 0.85$ & $2.23 \pm 0.40$ & $2.21 \pm 0.60$ & $5.29 \pm 2.54$ & $3.83 \pm 1.25$ & $3.07 \pm 0.94$ & 0.70 & 0.01 \\
\hline Lactate $^{d}$ & $2.39 \pm 0.78$ & $0.72 \pm 0.64$ & $1.06 \pm 0.90$ & $0.10 \pm 0.02$ & $0.85 \pm 0.79$ & $2.15 \pm 0.82$ & 0.14 & 0.22 \\
\hline $\mathrm{TDN}^{e}$ & $1.26 \pm 0.57 \mathrm{a}$ & $1.92 \pm 0.28 b$ & $3.76 \pm 0.34 c$ & $9.15 \pm 1.35$ & $5.03 \pm 1.53$ & $5.07 \pm 2.17$ & 0.002 & 0.04 \\
\hline $\mathrm{NH}_{4}^{+}-\mathrm{N}^{e}$ & $1.05 \pm 0.48 \mathrm{a}$ & $1.63 \pm 0.13 a$ & $2.63 \pm 0.47 b$ & $4.54 \pm 0.85$ & $4.17 \pm 1.33$ & $3.43 \pm 2.10$ & 0.015 & 0.05 \\
\hline $\mathrm{NO}_{3}{ }^{-}-\mathrm{N}^{e}$ & $0.25 \pm 0.15$ & $0.10 \pm 0.06$ & $0.23 \pm 0.37$ & $4.61 \pm 2.67$ & $0.33 \pm 0.40$ & $0.83 \pm 0.84$ & 0.61 & 0.10 \\
\hline DON-N ${ }^{e}$ & $<0.01 \mathrm{a}$ & $0.19 \pm 0.15 b$ & $0.91 \pm 0.17 \mathrm{c}$ & $<0.01$ & $0.53 \pm 0.52$ & $0.81 \pm 0.78$ & 0.002 & 0.65 \\
\hline $\operatorname{DAPI}^{f}$ & $2.05 \pm 0.07$ & $2.12 \pm 0.60$ & $3.84 \pm 1.32$ & $3.17 \pm 1.02$ & $3.90 \pm 1.80$ & $4.07 \pm 1.89$ & 0.10 & 0.19 \\
\hline $\mathrm{TSA}^{g}$ & $0.78 \pm 0.01 \mathrm{a}$ & $9.60 \pm 3.48 b$ & $26.4 \pm 1.22 \mathrm{c}$ & $21.2 \pm 12.7$ & $70.0 \pm 74.7$ & $73.3 \pm 15.6$ & 0.001 & 0.08 \\
\hline pTSA $^{h}$ & $0.04 \pm 0.01 \mathrm{a}$ & $0.45 \pm 0.03 b$ & $0.67 \pm 0.18 b$ & $0.77 \pm 0.65$ & $1.54 \pm 1.07$ & $1.98 \pm 0.70$ & 0.005 & 0.003 \\
\hline $\mathrm{R}_{2} \mathrm{~A}^{g}$ & $1.32 \pm 0.77 \mathrm{a}$ & $10.5 \pm 2.17 b$ & $24.2 \pm 14.9 \mathrm{~b}$ & $33.8 \pm 5.80$ & $27.1 \pm 7.62$ & $72.9 \pm 24.8$ & 0.003 & 0.14 \\
\hline $\mathrm{pR}_{2} \mathrm{~A}^{h}$ & $0.06 \pm 0.04 \mathrm{a}$ & $0.50 \pm 0.04 b$ & $0.61 \pm 0.21 b$ & $1.16 \pm 0.55$ & $0.78 \pm 0.41$ & $1.89 \pm 0.53$ & 0.01 & 0.03 \\
\hline $\operatorname{CSEA}^{g}$ & $1.02 \pm 0.20 \mathrm{a}$ & $14.6 \pm 2.53 b$ & $39.8 \pm 22.9 c$ & $35.0 \pm 23.6$ & $86.9 \pm 86.2$ & $113 \pm 44.4$ & $<0.001$ & 0.11 \\
\hline pCSEA $^{h}$ & $0.05 \pm 0.01 \mathrm{a}$ & $0.71 \pm 0.12 b$ & $1.01 \pm 0.29 b$ & $1.29 \pm 1.16$ & $1.94 \pm 1.11$ & $2.92 \pm 0.95$ & 0.01 & 0.002 \\
\hline
\end{tabular}

Data are mean values \pm S.D. Interspace values in the same row and denoted by different letters are significantly different at $\alpha=0.05$.

${ }^{a}$ One-way ANOVA interspace samples only, $F_{2,7}$.

${ }^{b}$ Two-way PROC MIXED ANOVA $F_{1,12}$.

$c_{0}$ Dry soil $(\mathrm{w} / \mathrm{w})$.

${ }^{d} \mu \mathrm{g} \mathrm{g}^{-1}$ dry soil. Note that TDOC, sugars, and TDOA were extracted with different methods and measured independently; thus, TDOC is not equal to the sum of sugars and TDOA.

${ }^{e} \mu \mathrm{g} \mathrm{N} \mathrm{g}{ }^{-1}$ dry soil. TDN is the sum of $\mathrm{NH}_{4}^{+}, \mathrm{NO}_{3}^{-}$, and DON.

$f_{\times} \times 10^{8} \mathrm{~g}^{-1}$ dry soil.

$g_{\times} 10^{5}$ CFU g ${ }^{-1}$ dry soil.

${ }^{h}$ Proportion of total DAPI-stained cells (\%). 
by DGGE under the same conditions as used for soil community analysis. Where differences in DGGE migration behavior were observed, the HaeIII ARDRA-type was considered to be a composite of several distinct phylotypes. Sequences representing the most common phylotypes have been submitted to GenBank (AY672655AY672670).

Phylogenetic Analysis. Chimeric sequences were identified with the Chimera Check tool [11] and three clones were excluded from further analysis. Remaining clone sequences and best matching sequences obtained from BLAST searches [1] for each clone sequence were subjected to phylogenetic analysis using the ARB program package [32]. Sequences were aligned using the ARB fast aligner to an existing database of $284916 \mathrm{~S}$ rRNA sequences based on the Ribosomal Database Project alignment. The alignment was manually checked and corrected. The phylogenetic tree was constructed based on maximum parsimony insertion of the new sequences. The tree was tested using maximum parsimony analysis with 100 bootstrap samples on the reduced species set selected for presentation.

Statistical Analysis. The effect of soil age on soil properties was examined through one-way analysis of variance (ANOVA) of the interspace samples, with Tukey's honestly significant difference (HSD) used as the means separation test. The overall effect of $L$. alpina was examined with the model $x=L$. alpina + soil age $+L$. alpina $\times$ soil age using the PROC MIXED procedure in SAS 9.1. Post hoc $t$-tests with Bonferroni corrections [38] were used to assess the difference between L. alpina rhizosphere and interspace samples at each time point along the chronosequence individually. We took this two-step approach to the analysis because initial analyses using the factorial model in PROC GLM (SAS 9.1) revealed significant and confounding interactions between soil age and $L$. alpina effects for 16 of the 22 variables examined. For both ANOVA procedures, normality and equivalence of variance assumptions were checked for all soil chemical and microbial parameters, and log transformations were performed where necessary.

The relationship between the number and proportion of culturable organisms and the soil chemical data were assessed by a species-centered and standardized redundancy analysis (RDA), and the significance of the correlation was determined by Monte Carlo permutation tests [47]. DCA was used to examine the similarity of the bacterial community DGGE profiles, and mean values of the quantitative environmental parameters were added to this ordination as supplementary passive variables. RDA and DCA were performed in CANOCO vs 4.5 (Biometris, Wageningen, The Netherlands).
A collector's curve for the $16 \mathrm{~S}$ rDNA clone library and values of Hurlbert's probability of interspecific encounter (PIE) [23] for the entire library and for each of the microhabitats represented within the library were calculated after rarefaction to a standard sample size using the Species Diversity package within ECOSIM [20].

\section{Results}

Soil Chemistry. The mean values for all soil chemical parameters in interspace and rhizosphere soils along the chronosequence are reported in Table 1. In the interspace soils, only $\mathrm{pH}$ and the concentrations of $\mathrm{DON}, \mathrm{NH}_{4}^{+}$, and total dissolved nitrogen (TDN) showed significant variation with soil age (Table 1). Generally, Tukey's
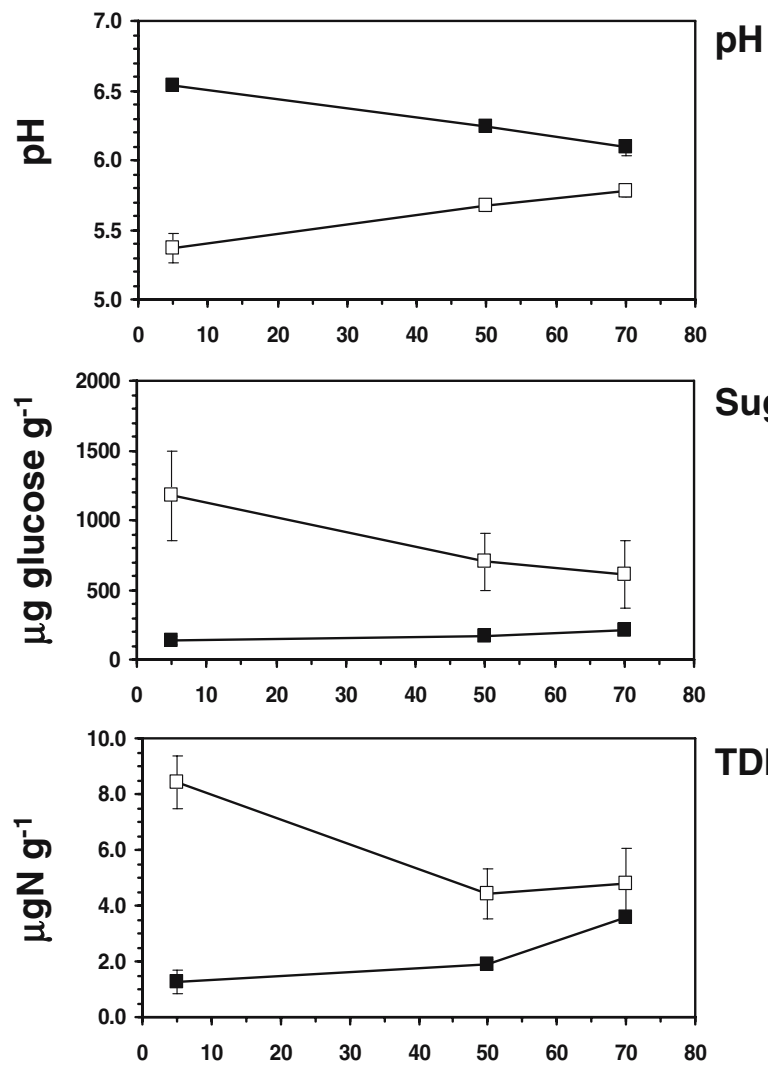

TDN

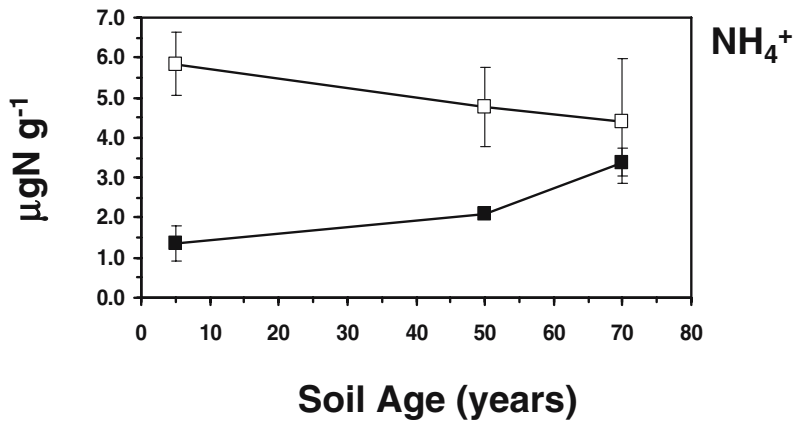

Figure 2. Chronosequence trends in $\mathrm{pH}$, soluble sugars, TDN, and ammonium. $\square$ Rhizosphere, $\mathbf{a}$ interspace. Error bars are \pm 1 SE. 
HSD tests indicated no significant difference between the mean values of these parameters in the 50 - and 70 -yearold soils, but indicated a clear difference between these and the youngest 5 -year-old soil (Table 1).

In comparison with the interspace soils, the rhizosphere of $L$. alpina was characterized by significantly lower $\mathrm{pH}$ and significantly higher concentrations of TOC, soluble sugars, ammonium, and TDN (Table 1). Interestingly, for $\mathrm{pH}$, soluble sugars, ammonium, and TDN concentrations, the magnitude of the difference between rhizosphere and interspace soils decreased steadily with increasing soil age (Fig. 2), whereas for concentrations of total DOC (TDOC), total dissolved organic acid (TDOA), and nitrate, the magnitude of the difference between rhizosphere and interspace soils decreased dramatically between 5 - and 50-year-old soils (Fig. 3). For TDOC, TDOA, and nitrate, there was therefore no significant overall rhizosphere effect (Table 1), although post
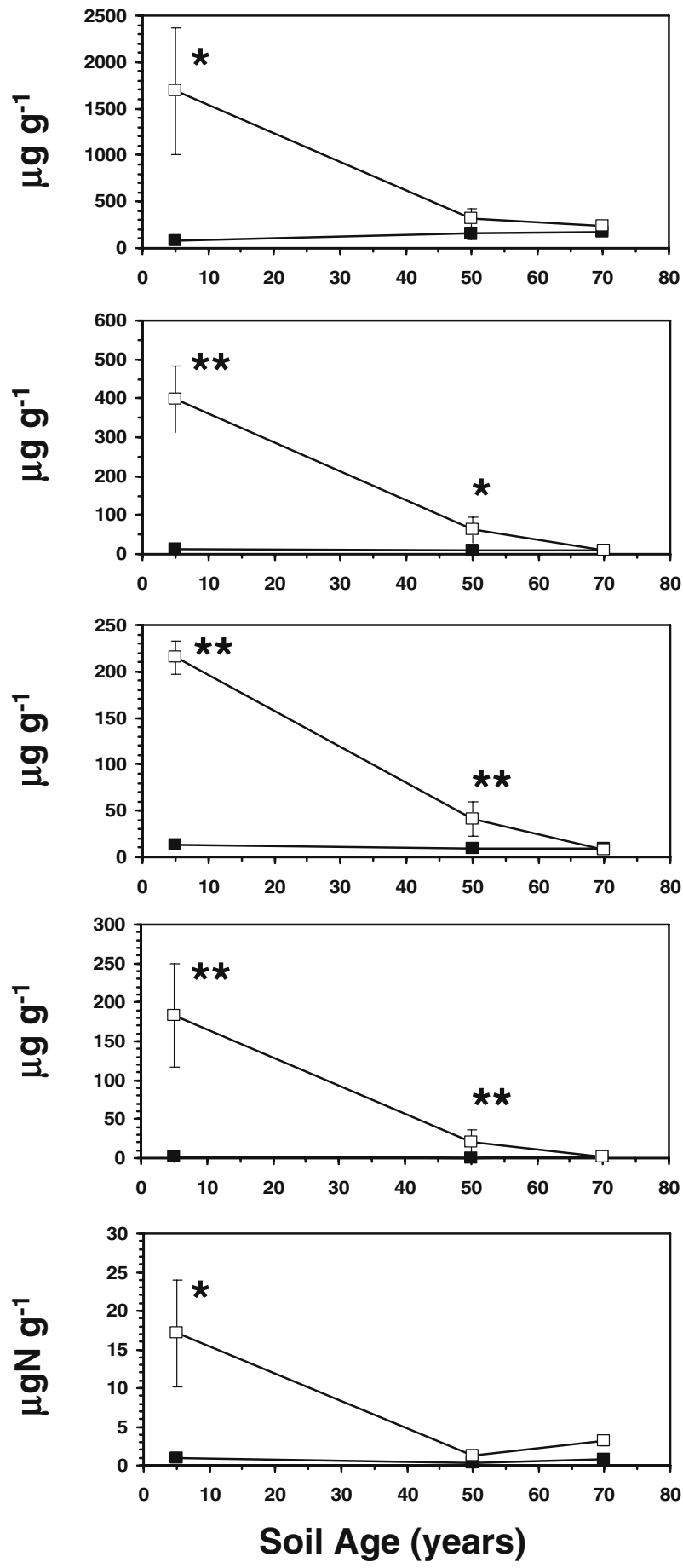

TDOC

TDOA

Citrate

Oxalate

\section{Nitrate}

Figure 3. Chronosequence trends in TDOC, TDOA, citrate, oxalate, and nitrate concentrations showing the strong conditionality of the "rhizosphere effect" for these parameters. $\square$ Rhizosphere, $\square$ interspace. Error bars are $\pm 1 \mathrm{SE}$, and the difference between rhizosphere and interspace is significant at $* p<0.05$ or ${ }^{* *} p<0.01$ at the time points indicated. 
hoc $t$-tests revealed that the concentrations of all of these parameters were significantly higher in the rhizosphere of L. alpina on the 5-year-old soils and that TDOA concentrations were also significantly higher in the rhizosphere of L. alpina on the 50-year-old soils (Fig. 3).

Of the six organic acids consistently recovered from all soil samples, citrate was the most abundant in both interspace and rhizosphere soils (Table 1) and represented $\sim 50 \%$ of TDOA. As for TDOA, higher concentrations of citrate tended to be recovered for the rhizosphere of L. alpina (Table 1), although the difference between rhizosphere and interspace concentrations was only significant in the 5- and 50-year-old soils (Fig. 3). In the L. alpina rhizosphere, oxalate was typically the second most abundant organic acid (Table 1), representing, on average, $20 \%$ of TDOA. In contrast to this, oxalate represented on average only $3.6 \%$ of TDOA in interspace soils, and these proportions were significantly different (one-sided $t$-test, $p=0.015$ ). Nevertheless, as for TDOA and citrate, concentrations of oxalate were only significantly higher in the rhizosphere of $L$. alpina than in the interspace in the 5- and 50-year-old soils (Fig. 3). Although concentrations of acetate, formate, malate, and lactate were often higher in L. alpina rhizosphere than interspace, these differences were not significant (Table 1). Acetate, however, did represent a significantly greater proportion of the interspace TDOA (mean interspace, 21\%; mean rhizosphere, 10\%; onesided $t$-test, $p=0.012$ ).

Total and Culturable Cell Numbers. The mean values for all microbiological parameters in interspace and rhizosphere soils along the chronosequence are reported in Table 1. In the interspace soils, total cell numbers estimated by DAPI generally increased with increasing soil age (Table 1), but this was not statistically significant. In contrast to this, soil age had a significant effect on both the number and the proportion of colony-forming units (CFU) recovered from interspace soils on TSA, $\mathrm{R}_{2} \mathrm{~A}$, and CSEA agars (Table 1). Generally, the number and proportion of cells recovered in the 50- and 70-year-old soils were similar, and significantly higher than observed in the youngest, 5-year-old soils (Table 1).

The presence of $L$. alpina had no significant effect on the total cell numbers estimated by DAPI overall (Table 1) or at any of the three individual time points (Fig. 4). ANOVA also revealed that the presence of $L$. alpina had no overall effect on the number of CFU recovered on TSA, $\mathrm{R}_{2} \mathrm{~A}$, or CSEA (Table 1), although for each of these media, numbers of CFU were significantly higher in the L. alpina rhizospheres of 5- and 50-year-old soils (Fig. 4). The culturable proportion of the bacterial community (i.e., pTSA, $\mathrm{pR}_{2} \mathrm{~A}$, and pCSEA) was significantly higher in L. alpina rhizosphere at all time points (Table 1).
Redundancy Analysis. The primary two axes of the RDA (Fig. 5) accounted for over $90 \%$ of the variation in culturable cells numbers and community culturability, and indicated a statistically significant correlation between bacterial colony counts and the chemistry of the environment from which the cells were recovered (Monte Carlo permutation tests $p=0.02,199$ permutations).

Molecular Analysis. A total of 85 HaeIII ARDRA types were recovered from the 120 clones that we
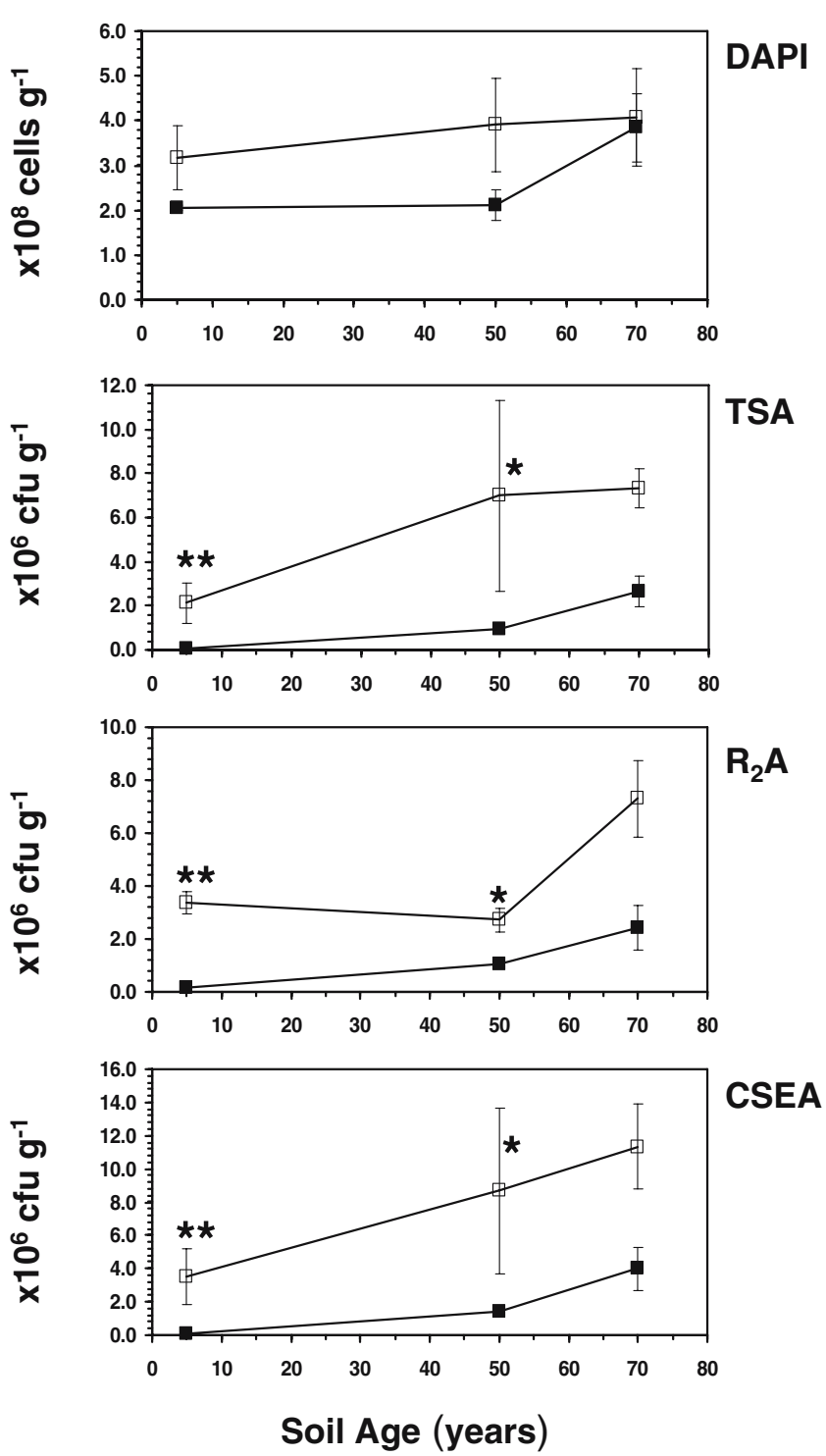

Figure 4. Chronosequence trends in total cell counts (DAPI) and in the numbers of culturable bacteria recovered on TSA, $\mathrm{R}_{2} \mathrm{~A}$, and CSEA nonselective plates. $\square$ Rhizosphere, $\mathbf{n}$ interspace. Error bars are \pm 1 SE, and the difference between rhizosphere and interspace is significant at $* p<0.05$ or $* * p<0.01$ at the time points indicated. 


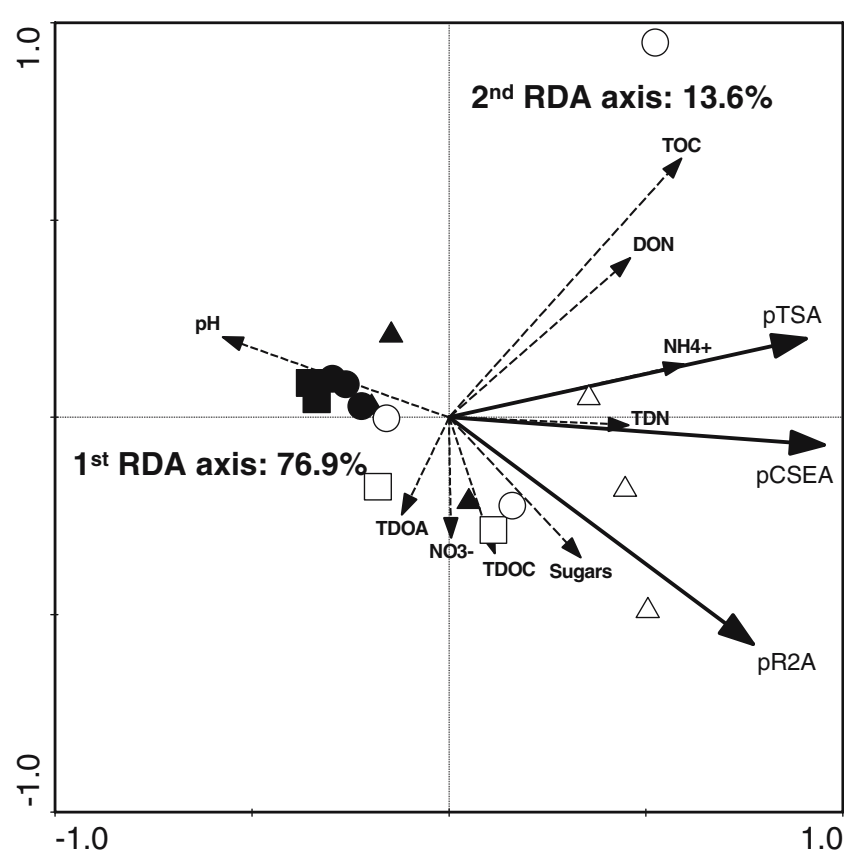

Figure 5. Species-centered and normalized biplot based on RDA and showing the relationship between the proportion of the bacterial community culturable on three nonselective agars and the soil chemistry of the samples from which the bacteria were extracted. Trends in culturability are shown as solid line vectors, and trends in soil variables by dashed line vectors. $\mathbf{a n} 5$, $\bullet$ In50, In70, $\square$ Rh5, $\circ \mathrm{Rh} 50, \triangle \mathrm{Rh} 70$.

examined. Sixty-seven of the ARDRA types were recovered only once, and the remaining 18 ARDRA types were recovered two to five times each. A collector's curve for the full library of 120 clones showed no evidence of reaching an asymptote (Fig. 6), indicating that bacterial $16 \mathrm{~S}$ rDNA diversity in the Dammaglacier forefield soils greatly exceeded the number of sequences recovered. To compare the relative diversities of the four microhabitats represented in the clone library (In5, Rh5, In70, and Rh70), we therefore calculated Hurlbert's PIE for each one separately. Mean PIE values for each microhabitat ranged from a low of 0.95 in Rh5 to a high of 1.0 in In5; however, examination of the $95 \%$ confidence intervals for these estimates provided no evidence of a significant decrease in bacterial diversity either in the rhizosphere of $L$. alpina or along the chronsequence (Fig. 6).

DGGE was used to assess the similarity of the six microenvironments in terms of their dominant bacterial populations. The DGGE patterns (Fig. 7) revealed clear differences between Rh5 and In5, and between both of these and all of the older soils, but no characteristic community associated with L. alpina rhizophere. DCA based on band-normalized relative intensity (Fig. 7) clustered the 50- and 70-year-old rhizosphere and interspace samples together, and indicated less of a difference between these communities and the 5-year rhizosphere sample than between 5-year rhizosphere and 5-year interspace.

High-quality nonchimeric sequences of the fragment of the $16 \mathrm{~S}$ rDNA gene amplified with the DGGE primer set were obtained from 12 of the 18 HaeIII ARDRA types that occurred more than once in the library, and subsequent Basic Local Alignment Search Tool (BLAST) searches returned strong matches to Pseudomonas, Pedobacter, Acidobacterium, and Aquaspirillum/Janthinobacterium 16S rDNA sequences for 5 of these 12 (Table 2). The remaining seven $16 \mathrm{~S}$ rDNA partial sequences could not be identified through BLAST (Table 2). A phylogenetic analysis (Fig. 8) provided strong support for the BLAST matches and, in addition, revealed that six of the seven unidentified sequences clustered together in a clade possibly related to the Cytophaga-Flexibacter-Bacteroides (CFB) group, whereas the seventh clustered with Pedobacter. Although, because of the short length of the analyzed 16S rRNA gene fragments (358-392 bp), the phylogenetic placement of the sequences is putative, the good agreement between BLAST results and phylogenetic analysis and high bootstrap values supporting most
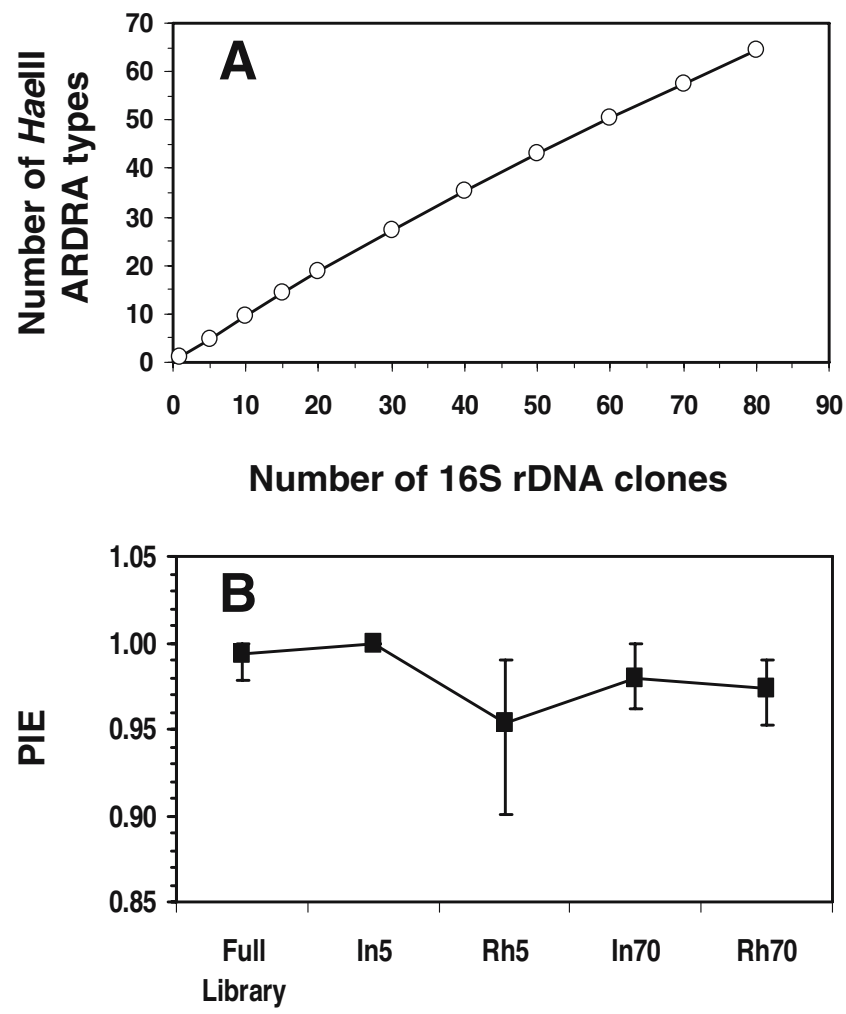

Microhabitat Library

Figure 6. (A) Collector's curve for the library of 120 randomly cloned 16S rDNA sequences recovered from the Damma forefield soils. (B) Variation in PIE values obtained for each of four Damma forefield microhabitats and for the full library of 120 clones. Error bars indicate 95\% confidence intervals for the estimates of PIE. 


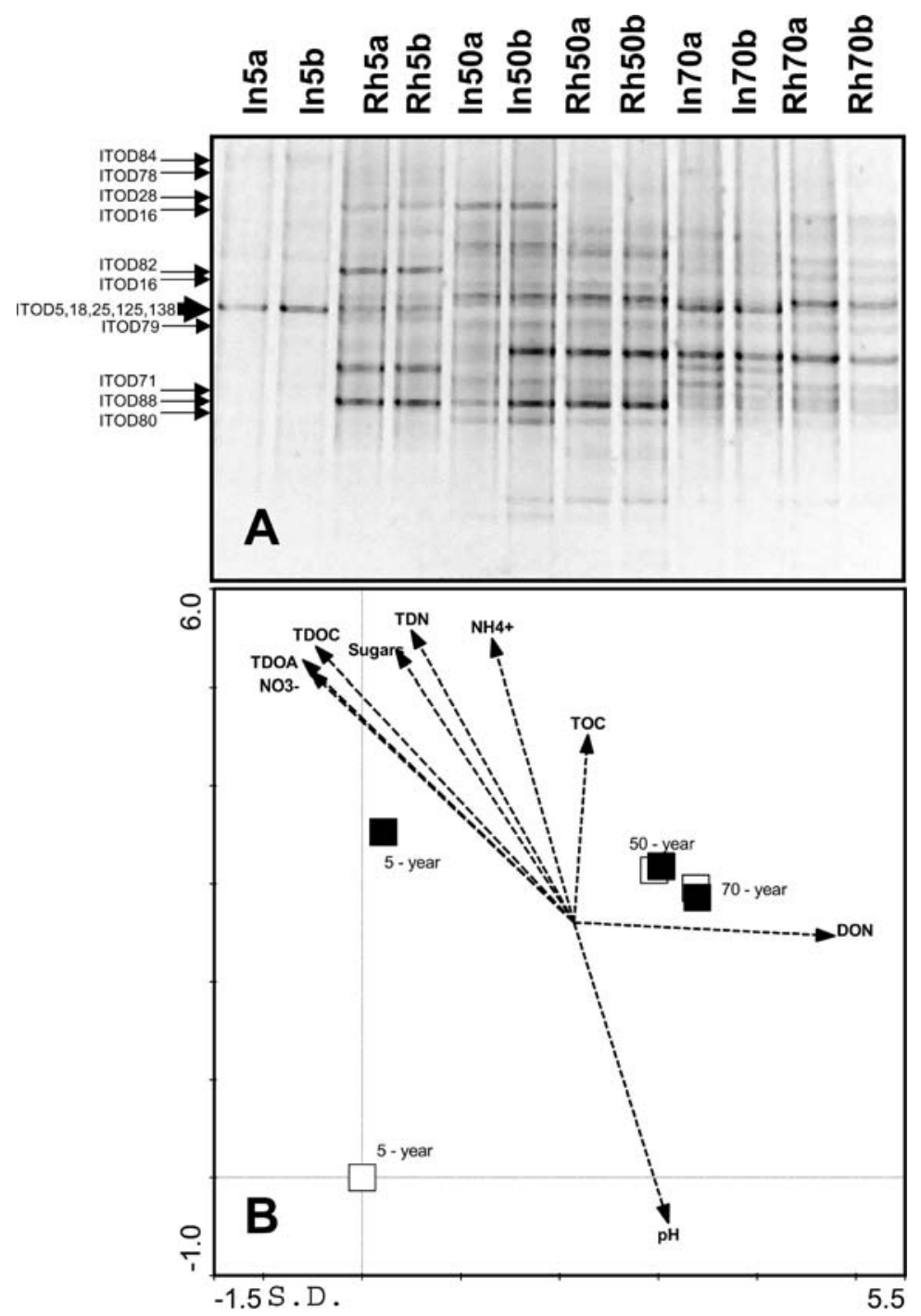

Figure 7. (A) DGGE patterns produced from $16 \mathrm{~S}$ rDNA templates isolates from interspace $(I n)$ and rhizosphere $(R h)$ samples across the Dammaglacier forefield chronosequence. Suffix $a$ and $b$ indicate separate PCR amplifications. Band migration distance of selected ITOD sequences is indicated. (B) DCA of $16 \mathrm{~S}$ rDNA DGGE phylotype distributions. The first axis explains $42 \%$ of the variance in phylotype relative abundance, and the second axis a further $22 \%$. Gradients in the underlying soil chemistry are plotted as passive vectors. $\square$ Rhizosphere, $\square$ interspace.

Table 2. BLAST search results for Dammaglacier forefield sequences

\begin{tabular}{|c|c|c|c|c|c|c|}
\hline Soil & Phylotype $e^{a}$ & $\begin{array}{l}\text { Abundance } \\
(\%)^{b}\end{array}$ & Sequenced clones & Best-match database sequence & $\begin{array}{l}\text { Percent } \\
\text { homology } \\
\quad(\%)\end{array}$ & $b p^{c}$ \\
\hline Rh5 & $\mathrm{A} 1$ & 16.7 & ITOD 80 (AY672664) & Antarctic bacterium (UBA 441004) & 99 & 388 \\
\hline Rh5 & A2 & - & ITOD 88 (AY672667) & Pseudomonas veronii (AY144583) & 98 & 383 \\
\hline Rh5/In5 & B1 & 10 & ITOD 84 (AY672666) & Pedobacter cryonitis (PCR 438170) & 98 & 381 \\
\hline $\operatorname{In} 5$ & $\mathrm{~B} 2$ & 3.3 & ITOD 78 (AY672663) & Pedobacter cryonitis (PCR 438170) & 99 & 377 \\
\hline Rh5 & $\mathrm{C}$ & 10 & ITOD 71 (AY672661) & Pseudomonas syringae (AF511511) & 99 & 394 \\
\hline Rh5 & D1 & 10 & ITOD 82 (AY672665) & Aquaspirillum autotrophicum (AB074524) & 99 & 370 \\
\hline Rh5 & D2 & - & ITOD 79 (AY672662) & Janthinobacterium lividum (AF174648) & 99 & 370 \\
\hline Rh70/In70 & E & $6.7 / 6.7$ & ITOD 28 (AY672669) & Uncultured Acidobacterium (AJ619064) & 98 & 352 \\
\hline Rh70 & $\mathrm{F}$ & 6.7 & ITOD 5 (AY672657) & Uncultured bacterium (AJ318124) & 91 & 344 \\
\hline Rh70 & G & 6.7 & ITOD 1 (AY672655) & Uncultured bacterium (AJ318124) & 91 & 344 \\
\hline Rh70 & $\mathrm{G}$ & 6.7 & ITOD 16 (AY672658) & Endosymbiont of Acanthamoeba (AY549545) & 97 & 379 \\
\hline Rh70 & $\mathrm{H}$ & 6.7 & ITOD 8 (AY672656) & Uncultured bacterium (AJ318124) & 90 & 350 \\
\hline Rh70 & I & 6.7 & ITOD 25 (AY672659) & Uncultured bacterium (AJ318124) & 90 & 340 \\
\hline In70 & $\mathrm{J}$ & 6.7 & ITOD 138 (AY672670) & Uncultured bacterium (AJ318124) & 89 & 340 \\
\hline $\operatorname{In} 70$ & $\mathrm{~K}$ & 6.7 & ITOD 125 (AY672660) & Uncultured bacterium (AJ576410) & 94 & 364 \\
\hline
\end{tabular}

${ }^{a}$ Each letter indicates a different HaeIII ARDRA pattern. Letters followed by a number are ARDRA types that were subsequently revealed to contain more than one DGGE phylotype.

${ }^{b}$ Abundance as percentage of 30 random clones.

${ }^{c}$ Sequence length in base pairs. 


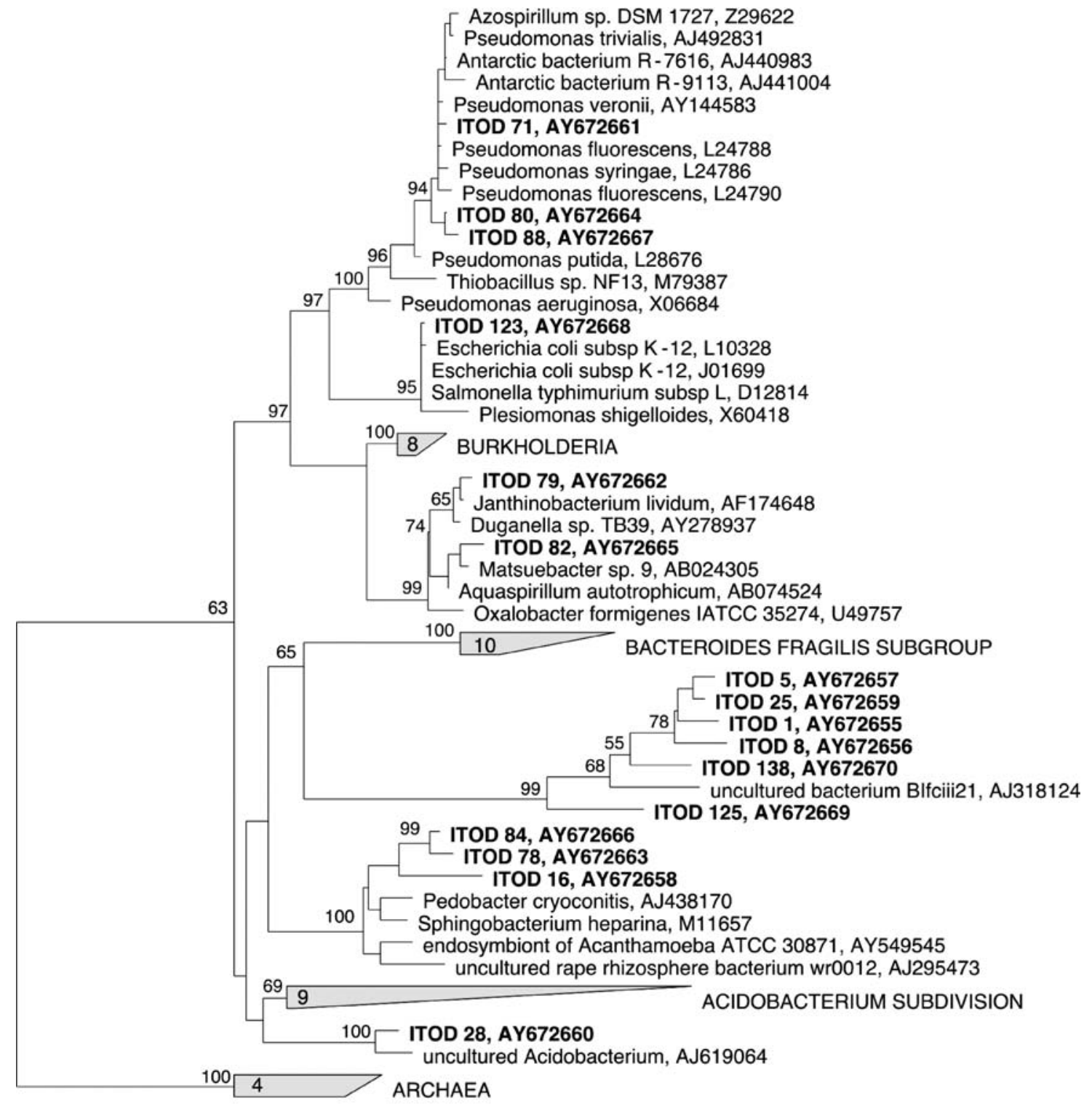

0.10

Figure 8. Maximum parsimony analysis of partial $16 \mathrm{~S}$ rRNA genes from 5- and 70-year-old rhizosphere and interspace microhabitats of the Dammaglacier forefield and published sequences. Percentage of 100 bootstrap samples supporting main branches is indicated if $>50 \%$. The number of species in collapsed groups is indicated in the shaded area.

of the branches containing clone sequences indicate that the current analysis is valid. Table 2 also shows that three of the HaeIII ARDRA types included sequence variation not sampled by restriction analysis, resulting in $15 \mathrm{com}-$ mon phylotypes. The DGGE migration distances for each of these 15 unique phylotypes under denaturing conditions are shown in Fig. 7.

\section{Discussion}

Glacier Forefield C and N Gradients. Previous studies in the forefields of the Damma [44] and other alpine glaciers [31, 41, 49] have suggested that the long-term development of the soil microbial community in such environments is at least partly driven by the accumulation of soil TOC and total nitrogen and by changes in soil $\mathrm{pH}$ over time. Although, in this study, we also examined longterm trends in total $\mathrm{C}$ and soil $\mathrm{pH}$, we primarily focused on labile, water-soluble forms of $\mathrm{C}$ and $\mathrm{N}$, because these are the most likely forms to be readily bioavailable to bacteria [24]. In addition, by concentrating on forms of labile $\mathrm{C}$ and $\mathrm{N}$, we were able to provide a more detailed comparison of rhizosphere and interspace soils along the chronosequence.

As with previous work [44], we found that soil TOC content increases rapidly in the Damma soils in the first 
50 years following deglaciation and then levels off (Table 1), and we show also that TDOC follows the same pattern of accumulation (Fig. 3). Despite this, because of a high degree of spatial heterogeneity, we found no significant difference between the TOC or TDOC contents of the interspace soils of increasing age (Table 1). In contrast, our study revealed that the ammonium, DON, and TDN contents of interspace soils increase steadily along the chronosequence, whereas concentrations of nitrate are unaffected (Table 1). The principal geochemical gradient that we observe in the 70-year chronosequence is therefore one of increasing $\mathrm{N}$ availability. A similar pattern of labile $\mathrm{N}$ accumulation during the first decades of primary succession has been reported on the floodplain sediments of the Tanana River, Alaska [26], and in both cases a small but steady supply of atmospheric nitrogen deposition may account for much of this increase. Interestingly, it can also be seen from our results (Table 1) that the proportion of DON in the labile $\mathrm{N}$ pool also increases with time, from $<1 \%$ in the youngest soils to $\sim 24 \%$ in the oldest, whereas that of nitrate decreases. Increased DON suggests biological transformation, and the consequence is a qualitative as well as a quantitative change to the labile $\mathrm{N}$ pool over the 65-year period that we examined.

The colonization of deglaciated soils by vascular plants and bryophytes begins early in the Damma forefield, and isolated individuals of L. alpina can be found just a few meters from the glacier toe (I. Edwards, personal observation). In comparison with the interspace soils, our results clearly show that the rhizosphere created by $L$. alpina has a significantly higher TOC content (Table 1) and contains significantly higher concentrations of soluble sugars, ammonium, and TDN at all time points along the chronosequence (Fig. 2). Unexpectedly, however, inspection of Table 1 and Fig. 2 shows that the magnitude of the difference between rhizosphere and interspace was much less in the oldest soils than in the youngest, and that this could not be fully explained by increased concentrations of, e.g., ammonium or TDN in the interspace of the oldest soils. This apparent "conditionality" of the L. alpina rhizosphere effect was most clearly seen for TDOC and TDOA (Fig. 3) where rhizosphere concentrations were up to 20-fold higher than interspace in the youngest soils, but were no longer significantly different in the oldest soils despite little increase in the TDOC or TDOA concentrations of the interspace. Although the precise source of the organic acids in soil solution cannot be known without ${ }^{14} \mathrm{C}$ tracer experiments, both citric and especially oxalic acids are commonly reported to be major components of plant rhizodeposits $[4,24]$ and were the major components of TDOA in the L. alpina rhizosphere soils. As the decline in rhizosphere TDOA was primarily because of a dramatic reduction in the quantity of citric and oxalic acids recovered from older soils, and as TDOA and TDOC were strongly correlated, we feel that our results may point to differences in L. alpina exudation patterns across this chronosequence. The reason for this is not clear, but may be related to the nutritional status of L. alpina at the various time points. For example, increased carboxylic acid exudation has been linked to phosphorous deficiency in several plant species $[12,36]$. Further studies should therefore seek to elucidate the nutritional stress experienced by pioneering plant species, such as L. alpina, and to examine their rhizodeposition response to such stress.

Microbial Community Size and Culturability. Previous work in the Damma glacier forefield has shown that the size of the bacterial community in 50-year-old soil can be 200-400 times larger than in the ice at the glacier toe, but that the size of the community is only slightly affected by soil age beyond this point [44]. Our results broadly agree with this in that we found no significant difference in the size of the bacterial communities recovered from the interspace along the 5- to 70-year chronosequence (Table 1). Surprisingly, given the tendency for increased C and N availability in the rhizosphere of L. alpina discussed above, we also found no evidence to suggest that rhizosphere bacterial communities were significantly larger than their interspace counterparts (Table 1; Fig. 4). In contrast, recent work in the forefield of the Rotmoos glacier, Austria [49], has shown larger microbial biomass in the rhizosphere of Poa alpina than in interspace soils, although this difference was only apparent in older soils (75 and 9500 years). Direct comparison of our results and those of Tscherko et al. [49] is not possible, however, as we did not determine cell volume.

Although the size of the bacterial community in the Damma forefield was not strongly affected either by soil age or by the presence of L. alpina, the numbers of culturable cells increased with soil age and were also much higher in the rhizosphere (Table 1). However, the magnitude of the rhizosphere effect on culturability showed the same trend as the TDOA, citrate, and oxalate concentrations (Figs. 3 and 4), with maximal difference in the youngest soil and minimal difference in the oldest soils. Bacterial species culturable on nonselective media are often considered as copiotrophs or $\mathrm{r}$-selected generalists [29], and it has been proposed that the degree of culturability, defined as the ratio of culturable to total cells [18], should decrease over time as the number of $\mathrm{r}$ selected species in the community declines [17]. The culturability of the forefield bacterial communities ranged from 0.04 to $2.92 \%$ (Table 1) and, surprisingly, the highest degree of culturability was observed in the rhizosphere of L. alpina growing on 70-year-old soils. Perhaps even more surprisingly, the culturability of the microbial communities recovered from 70-year-old interspace was very similar to that seen in the L. alpina rhizosphere of the 5-year-old soils (Fig. 4). A previously 
proposed relationship between "successional stage" and culturability [18] is therefore not supported by our results, and we further examined the relationship between culturability and $\mathrm{C}$ and $\mathrm{N}$ availability through RDA. In a species-centered and standardized RDA, the length and direction of the vectors representing species and environmental variables provides a visual indication of the magnitude of the correlation between these and the redundancy axes [47]. The RDA (Fig. 5) indicated that the size and proportion of the culturable fraction in the Damma forefield microbial communities is most likely determined by the interactive effects of plant colonization and soil age on $\mathrm{C}$ and $\mathrm{N}$ availability; the primary RDA axis separated interspace from rhizosphere communities, but also separates the communities within each of these classes on the basis of soil age (Fig. 5). This primary axis, which therefore incorporates both plant and age factors, is most strongly correlated to the TDN gradient. The secondary RDA axis further distinguishes interspace from rhizosphere communities, and this axis is most strongly correlated with labile carbon availability. Our results therefore suggest that the microbial community of the youngest soils in the Damma forefield is dominated by populations of nonculturable cells, which correspond to stress-tolerant or K-selected species, and that the size of $r$-selected species populations (culturable on nonselective media) increases over the first 70 years of succession, as nitrogen availability increases, or in the rhizosphere of a colonizing plant, where $\mathrm{C}$ and $\mathrm{N}$ availability increases.

\section{Glacier Forefield Geochemical Gradients and Micro-} bial Community Composition. Several studies have shown that distinct microbial communities can develop in the rhizospheres of individual plant species growing in the same soil $[19,28,34,51,52]$. At the same time, differences have been observed between the rhizosphere microbial communities of several plant species when these species are grown in different soils [51]. Our results (Fig. 7) showed several dominant bacterial populations in the DGGE fingerprint obtained from the rhizosphere of L. alpina in the 5-year-old soil that are not present in the community fingerprint obtained from the interspace soil. Based on the DGGE migration distance of the $16 \mathrm{~S}$ rDNA clones recovered from these soils, many of these dominant rhizospheric populations could be putatively assigned to be members of the Pseudomonaceae, Sphingomonaceae, and Oxalobacteriaceae (Fig. 7). The DGGE fingerprints (Fig. 7) also show that the age of the soil in the Damma forefield affects the dominant bacterial populations in both the interspace and the rhizosphere, and that the difference between the composition of the bacterial communities in L. alpina rhizosphere and interspace soil decreases with increasing soil age. Our second hypothesis, that $L$. alpina would be associated with a distinct rhizosphere community, was therefore rejected. As such, our results tend to agree with those studies of agronomic plant species that have indicated a soil effect [51]. Plotting the soil chemical data as vectors onto the DCA enabled us to examine the patterns of microbial community similarity in terms of the environmental gradients, and the degree to which the bacterial communities of the Damma forefield differed in composition strongly mirrored the differences in underlying soil chemistry (Fig. 7). Our results therefore suggest that shifts in the composition of the dominant microbial populations in the rhizosphere are primarily the result of increased soluble carbon and mineral nitrogen availability, whereas the long-term shifts in the community seen with increasing soil age may be more related to an increased availability of labile nitrogen. Interestingly, our results with $L$. alpina differ from those presented by Tscherko et al. [49], which tended to show that the influence of the grass $P$. alpina on microbial community composition increased with increasing soil age. Both L. alpina and $P$. alpina are recognized as pioneer species in the glacier forefield environment [6]. The reason for their apparently quite different effects on the rhizosphere microbial community is not clear. The difference may in part be because of differing analytical methodology: our DNAbased analysis targeted only the bacterial community, whereas Tscherko et al. [49] showed a pronounced reduction in the fungal component of the $P$. alpina rhizosphere with increasing soil age. In addition, we sampled plants very soon after snowmelt in the spring, whereas Tscherko et al. [49] sampled close to the end of the alpine growing season in September. As noted above, the extent to which proximity to a glacier affects either the degree of nutritional stress experienced by pioneering plants or the dynamics of plant activity is not yet clear.

\section{Conclusion}

In conclusion, our results support the hypothesis that a long-term gradient in $\mathrm{N}$ availability can develop in recently deglaciated soils, and that this can influence both the culturability and the composition of the bacterial communities. However, we found no clear evidence for a $\mathrm{C}$ gradient within the 70 -year time frame that we examined. Our results also show that pioneering vascular plants such as L. alpina can increase $\mathrm{C}$ and $\mathrm{N}$ availability in their root zone and create a clear "rhizosphere effect" characterized by both a sharp increase in the degree of culturability of the microbial community and a shift in the dominant bacterial populations. For L. alpina, our results further showed that the magnitude of the rhizosphere effect was maximal in the earliest and most nutrient-poor soils, and was much smaller in older soils. 
The high concentrations of oxalic acid in the rhizosphere of 5-year-old soils suggests that these soils are a stressful environment for $L$. alpina growth, possibly because of nutrient limitations, and that the plant compensates for this through increased levels of rhizodeposition. The increased culturability of the microbial communities recovered from older soils, together with much smaller evidence of population shifts in the L. alpina rhizosphere, suggests that the proportion of $\mathrm{r}$-selected species in the bacterial community increases during the first 70-100 years of primary succession on nutrient-poor alpine soils.

\section{References}

1. Altschul, SF, Gish, W, Miller, W, Myers, EW, Lipman, DJ (1990) Basic local alignment search tool. J Mol Biol 215: 403-410

2. Amann, RI, Luwig, W, Schleifer, KH (1995) Phylogenetic identification and in situ detection of individual microbial cells without cultivation. Microbiol Rev 59: 143-169

3. Baleshtra, GM, Misaghi, IJ (1997) Increasing the efficiency of the plate counting method for estimating bacterial diversity. J Microbiol Methods 30: 111-117

4. Barber, DA, Martin, JK (1976) The release of organic substances by cereal roots into soil. New Phytol 76: 69-80

5. Brodie, E, Edwards, S, Clipson, N (2002) Bacterial community dynamics across a floristic gradient in a temperate upland grassland ecosystem. Microb Ecol 44: 260-270

6. Burga, CA, Frauenfelder, R, Ruffet, J, Hoelzle, M, Kääb, A (2004) Vegetation on Alpine rock glacier surfaces: a contribution to abundance and dynamics on extreme plant habitats. Flora 199: 505-515

7. Bürgmann, H, Pesaro, M, Widmer, F, Zeyer, J (2001) A strategy for optimizing quality and quantity of DNA extracted from soil. J Microbiol Methods 45: 7-20

8. Chabrerie, O, Laval, K, Puget, P, Desaire, S, Alard, D (2003) Relationship between plant and soil microbial communities along a successional gradient in a chalk grassland in north-western France. Appl Soil Ecol 24: 43-56

9. Chapin, FS III, Walker, LR, Fastie, CL, Sharman, LC (1994) Mechanisms of primary succession following deglaciation at glacier bay, Alaska. Ecol Monogr 64: 149-175

10. Cheng, W, Zhang, Q, Coleman, DC, Carroll, CR, Hoffman, CA (1996) Is available carbon limiting microbial respiration in the rhizosphere? Soil Biol Biochem 28: 1283-1288

11. Cole, JR, Chai, B, Marsh, TL, Farris, RJ, Wang, Q, Kulam, SA, Chandra, S, McGarrell, DM, Schmidt, TM, Garrity, GM, Tiedje, JM (2003) The Ribosomal Database Project (RDP-II): previewing a new autoaligner that allows regular updates and the new prokaryotic taxonomy. Nucleic Acids Res 31: 442-443

12. Deubel, A, Gransee, A, Merbach, W (2000) Transformation of organic rhizodepositions by rhizosphere bacteria and its influence on the availability of tertiary calcium phosphate. J Plant Nutr 163: 387-392

13. Duineveld, B, Rosado, AS, van Elsas, JD, van Veen, JA (1998) Analysis of the dynamics of bacterial communities in the rhizosphere of the Chrysanthemum via denaturing gradient gel electrophoresis and substrate utilization patterns. Appl Environ Microbiol 64: 4950-4957

14. Duineveld, B, Kowalchuk, GA, Keijzer, A, van Elsas, JD, van Veen, JA (2001) Analysis of bacterial communities in the rhizosphere of Chrysanthemum via denaturing gradient gel electrophoresis of PCR-amplified 16S rRNA as well as DNA fragments coding for 16S rRNA. Appl Environ Microbiol 67: 172-178
15. Egli, M, Mirabella, A, Fitze, P (2001) Weathering and evolution of soils formed on granitic, glacial deposits: results from chronosequences of Swiss alpine environments. Catena 45: 19-47

16. Ekblad, A, Nordgren, A (2002) Is growth of soil microorganisms in boreal forests limited by carbon or nitrogen availability? Plant Soil 242: 115-122

17. Felske, A, Wolterink, A, Van Lis, R, De Vos, WM, Akkermans, ADL (2000) Response of a soil bacterial community to grassland succession as monitored by $16 \mathrm{~S}$ rRNA levels of the predominant ribotypes. Appl Environ Microbiol 66: 3998-4003

18. Garland, JL, Cook, KL, Adams, JL, Kerkhof, L (2001) Culturability as an indicator of succession in microbial communities. Microb Ecol 42: 150-158

19. Germida, JJ, Siciliano, SD, de Freitas, JR, Seib, AM (1998) Diversity of root-associated bacteria associated with field-grown canola (Brassica napus L.) and wheat (Triticum aestivum L). FEMS Microbiol Ecol 26: 43-50

20. Gotelli, NJ, Entsminger, GL (2001) EcoSim: Null Models Software for Ecology. Version 7.0. Acquired Intelligence Inc. \& Kesey-Bear, Jericho, VT

21. Hamelin, J, Fromin, N, Tarnawski, S, Teyssier-Cuvelle, S, Aragmo, M (2002) nifH gene diversity in the bacterial community associated with the rhizosphere of Molinia coeruea, an oligonitrophilic perennial grass. Environ Microbiol 4: 477-481

22. Hoelzle, M, Vonder-Mühll, D, Maisch, M (1999) Die Gletscher der Schweizer Alpen im Jahr 1997/1998. Die Alpen 10: 28-40

23. Hurlbert, SH (1971) Nonconcept of species diversity—critique and alternative parameters. Ecology 52: 577-586

24. Hütsch, BW, Augustin, J, Merbach, W (2002) Rhizodeposition-an important source for carbon turnover in soils. J Plant Nutr 165: 397-407

25. Jonasson, S, Michelsen, A, Schmidt, IK, Nielsen, EV, Callaghan, TV (1995) Microbial biomass C, N, and P in two arctic soils and responses to addition of NPK fertilizer and sugar: implications for plant nutrient uptake. Oecologia 106: 507-515

26. Kaye, JP, Binkley, D, Rhoades, C (2003) Stable soil nitrogen accumulation and flexible organic matter stoichiometry during primary floodplain succession. Biogeochemistry 63: 1-22

27. Körner, C (1999) Alpine Plant Life. Springer-Verlag, Berlin, pp 63-74

28. Kuske, CR, Ticknor, LO, Miller, ME, Dunbar, JM, Davis, JA, Barns, SM, Belnap, J (2002) Comparison of soil bacterial communities in rhizospheres of three plant species and the interspaces in an arid grassland. Appl Environ Microbiol 68: 1854-1863

29. Langer, U, Böhme, L, Böhme, F (2004) Classification of soil microorganisms based on growth properties: a critical view of some commonly used terms. J Plant Nutr Soil Sci 167: 267-269

30. Lilley, AK, Fry, JC, Bailey, MJ, Day, MJ (1996) Comparison of aerobic heterotrophic taxa isolated from four root domains of mature sugar beet (Beta vulgaris). FEMS Microbiol Ecol 21: 231-242

31. Lipson, DA, Schmidt, SK, Monson, RK (1999) Links between microbial population dynamics and nitrogen availability in an alpine ecosystem. Ecology 80: 1623-1631

32. Ludwig, W, Strunk, O, Westram, R, Richter, L, Meier, H, Buchner, A, Lai, T, Steppi, S, Jobb, G, Förster, W, Brettske, I, Gerber, S, Ginhart, AW, Gross, O, Grumann, S, Hermann, S, Jost, R, König, A, Liss, T, Lümann, R, May, M, Nonhoff, B, Reichel, B, Strehlow, R, Stamatakis, A, Stuckmann, N, Vilbig, A, Lenke, M, Ludwig, T, Bode, A, Schleifer, K-H (2004) ARB: a software environment for sequence data. Nucleic Acids Res 32: 1363-1371

33. Margesin, R, Spröer, C, Schumann, P, Schinner, F (2003) Pedobacter cryonitis sp. nov., a facultative psychrophile from alpine glacier cryoconite. Int J Syst Evol Microbiol 53: 1291-1296

34. Marilley, L, Aragno, M (1999) Phylogenetic diversity of bacterial communities differing in degree of proximity of Lolium perenne and Trifolium repens roots. Appl Soil Ecol 13: 127-136 
35. McCaig, AE, Glover, LA, Prosser, JI (2001) Numerical analysis of grassland bacterial community structure under different land management regimens by using $16 \mathrm{~S}$ ribosomal DNA sequence data and denaturing gradient gel electrophoresis banding patterns. Appl Environ Microbiol 67: 4554-4559

36. Merbach, W, Mirus, E, Knof, G, Remus, R, Ruppel, S, Russow, R, Gransee, A, Schultze, J (1999) Release of carbon and nitrogen compounds by plant roots and possible ecological importance. J Plant Nutr 162: 373-383

37. Mulvaney, RL (1996) Nitrogen-inorganic forms. In: Methods of Soil Analysis, Part 3. Chemical Methods-SSSA Book Series No. 5. Soil Science Society of America and American Society of Agronomy, Madison, WI, pp 1123-1184

38. Neter, J, Wasserman, W, Kutner, MH (1990) Applied Linear Statistical Models, 3rd ed., Irwin, Boston, MA, pp 741-744

39. Nübel, U, Engelen, B, Felske, A, Snaidr, J, Weishuber, A, Amann, RI, Ludwig, W, Backhaus, H (1996) Sequence heterogeneities of genes encoding $16 \mathrm{~S}$ rRNAs in Paenibacillus polymyxa detected by temperature gradient gel electrophoresis. J Bacteriol 178: 56365643

40. Oerlemans, J (1994) Quantifying global warming from the retreat of glaciers. Science 264: 243-245

41. Ohtonen, R, Fritze, H, Pennanen, T, Jumpponen, A, Trappe, J (1999) Ecosystem properties and microbial community changes in primary succession on a glacier forefront. Oecologia 119: 239-246

42. Roberts, MS, Garland, JL, Mills, AL (2004) Microbial astronauts: assembling microbial communities for advanced life support systems. Microb Ecol 47: 137-149

43. Sambrook, J, Fritsch, EF, Maniatis, T (1989) Molecular Cloning, A Laboratory Manual. Cold Spring Harbor Laboratory Press, Cold Spring Harbor, NY

44. Sigler, WV, Zeyer, J (2002) Microbial diversity and activity along the forefields of two receding glaciers. Microb Ecol 43: 397-407
45. Smith, JL, Paul, EA (1990) The significance of soil microbial biomass estimations. In: Bollag J, Stotsky G (Eds.) Soil Biochemistry, vol. 6. Marcel Dekker, New York, pp 357-396

46. Spreafico, M, Weingartner, R, Leibundgut, C (1992) Hydrological Atlas of Switzerland. Landeshydrologie und geologie, Bern, Switzerland

47. Ter Braak, CJF, Prentice, IC (1988) A theory of gradient analysis. Adv Ecol Res 18: 271-318

48. Thomas, GW (1996) Soil pH and soil acidity. In: Methods of Soil Analysis, Part 3. Chemical Methods-SSSA Book Series No. 5. Soil Science Society of America and American Society of Agronomy, Madison, WI, pp 475-490

49. Tscherko, D, Hammesfahr, U, Marx, M-C, Kandeler, E (2004) Shifts in rhizosphere microbial communities and enzyme activity of Poa alpina across an alpine chronosequence. Soil Biol Biochem 36: $1685-1698$

50. Tscherko, D, Rustemeier, J, Richter, A, Wanek, W, Kandeler, E (2003) Functional diversity of the soil microflora in primary succession across two glacier forelands in the Central Alps. Eur J Soil Sci 54: 685-696

51. Westover, KM, Kennedy, AC, Kelley, SE (1997) Patterns of rhizosphere microbial community structure associated with cooccurring plant species. J Ecol 85: 863-873

52. Wieland, G, Neumann, R, Backhaus, H (2001) Variation of microbial communities in soil, rhizosphere, and rhizoplane in response to crop species, soil type, and plant development. Appl Environ Microbiol 67: 5849-5854

53. Zarda, B, Hahn, D, Chatzinotas, A, Schönhuber, W, Neef, A, Amann, RI, Zeyer, J (1997) Analysis of bacterial community structure in bulk soil by in situ hybridization. Arch Microbiol 168: 185-192

54. Zhou, J, Chen, Z, Li, S (2003) Oxidation efficiency of different oxidants of persulfate method used to determine total nitrogen and phosphorus in solutions. Commun Soil Sci Plant Anal 34: 725-734 